\title{
La campagna d'Egitto: il contributo essenziale di Bonaparte e Monge alla moderna egittologia
}

\author{
Daniele Giovanni Papi
}

Abstract

II 15 luglio del 1799, durante i lavori di riparazione di Fort Julien, nella città di Rosetta, sul delta del Nilo (l'odierna Rashid), un soldato semplice rimasto anonimo, agli ordini del capitano Pierre Bouchard, si trovò di fronte un blocco di basalto nero ricoperto di iscrizioni. La superficie era suddivisa in tre settori: una lunga sequenza geroglifica, un testo in antico demotico e uno in greco. Per ordine del generale Jacques François Menou, la stele fu trasportata ad Alessandria e af-fidata ad alcuni classicisti che erano al seguito della spedizione napoleonica. Essi iniziarono la traduzione della parte in greco (abbandonata, poi ripresa, infine ultimata nel I 803), un decreto di Tolomeo V, e immaginarono che il testo demotico e quello geroglifico ne fossero la trascrizione.

Ci vollero due decadi ma, nel 1822, Jean François Champollion, al quale erano rimaste le copie a contatto che la Commission des Sciences et des Arts aveva fatto eseguire prima che, nel I80 I, la stele fosse accorpata al bottino di guerra che gli Inglesi pretesero, dopo la sconfitta di Napoleone, riuscì a decifrare i caratteri geroglifici.

La tradizione culturale dell'Occidente fa risalire a questo l'inizio della moderna egittologia, tuttavia riteniamo che sia possibile valutare gli eventi in modo leggermente diverso e sostenere che almeno una battaglia per il disegno, sia stata consapevolmente sostenuta nella storia.

Parole chiave

Monge, Egitto, Napoleone, archeologia, campagna
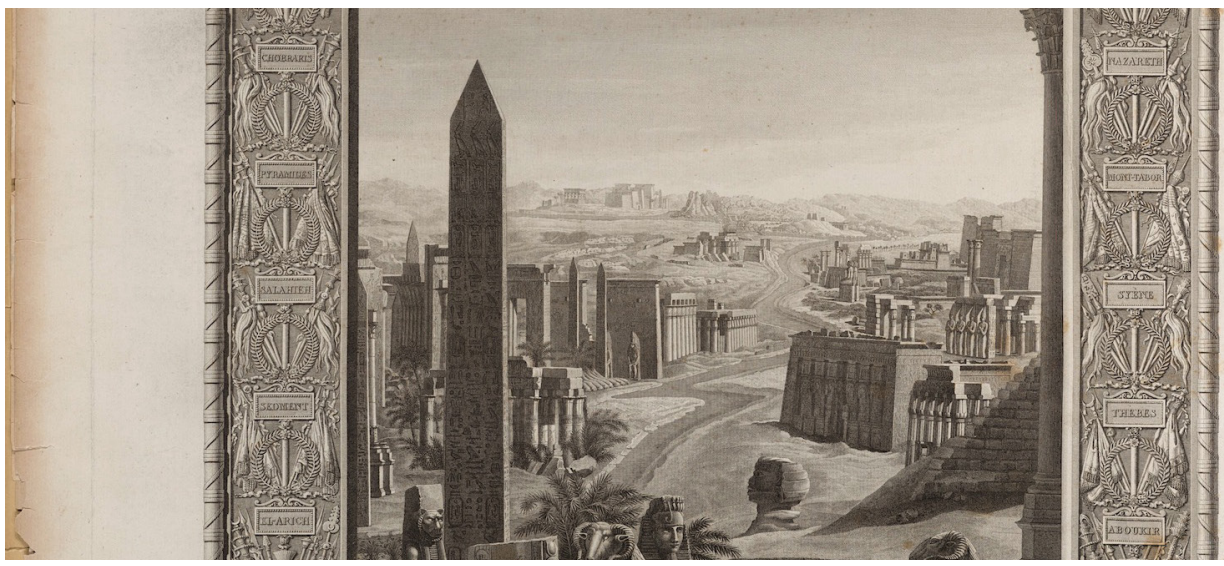


\section{L'Egitto, mito e storia}

A partire dal ritrovamento cinquecentesco di una statua di Iside nel sottosuolo di Torino, in Europa, era via via invalsa una forma di curiosità crescente verso tutto ciò che era egizio. Tale interesse crebbe fino a tutto il XVIII secolo, quando si può parlare della prima vera e propria 'egittomania' (la seconda sarà negli anni '20 del XX secolo dopo la scoperta di Howard Carter che viola la tomba di Tut-Ankh-Amon). Proprio nel corso del XVIII secolo, tradizionalmente attraverso il contributo di Winkelmann, il collezionismo tende a diventare archeologia e iniziano le prime domande scientifiche iniziano ad essere poste. Le istanze analitiche e metodologiche lentamente prendono il posto di quello che era stato, fino a quel punto, essenzialmente un fenomeno di costume [I]. Questo, come ovvio, non pone bruscamente ordine nella considerazione dei reperti e delle testimonianze legate alle rovine ma rappresenta una presa di coscienza della civiltà occidentale verso il passato.

Lo stesso Giovan Battista Piranesi, nel 1769, pubblica le Diverse maniere di adornare i cammini, un volume ricchissimo di decorazioni esplicitamente dette 'all'egizia' (fig. I) [2].

Possiamo bene immaginare come il mistero nascosto negli indecifrabili geroglifici, sovente ricondotti al ruolo simbolico di iscrizioni magiche piuttosto che a quello di scrittura vera e propria, contrastasse la svolta verso lo studio analitico.

Fig. I. G.B. Piranesi, Diverse maniere di adornare i cammini, Tavola 14 Roma, 1769.

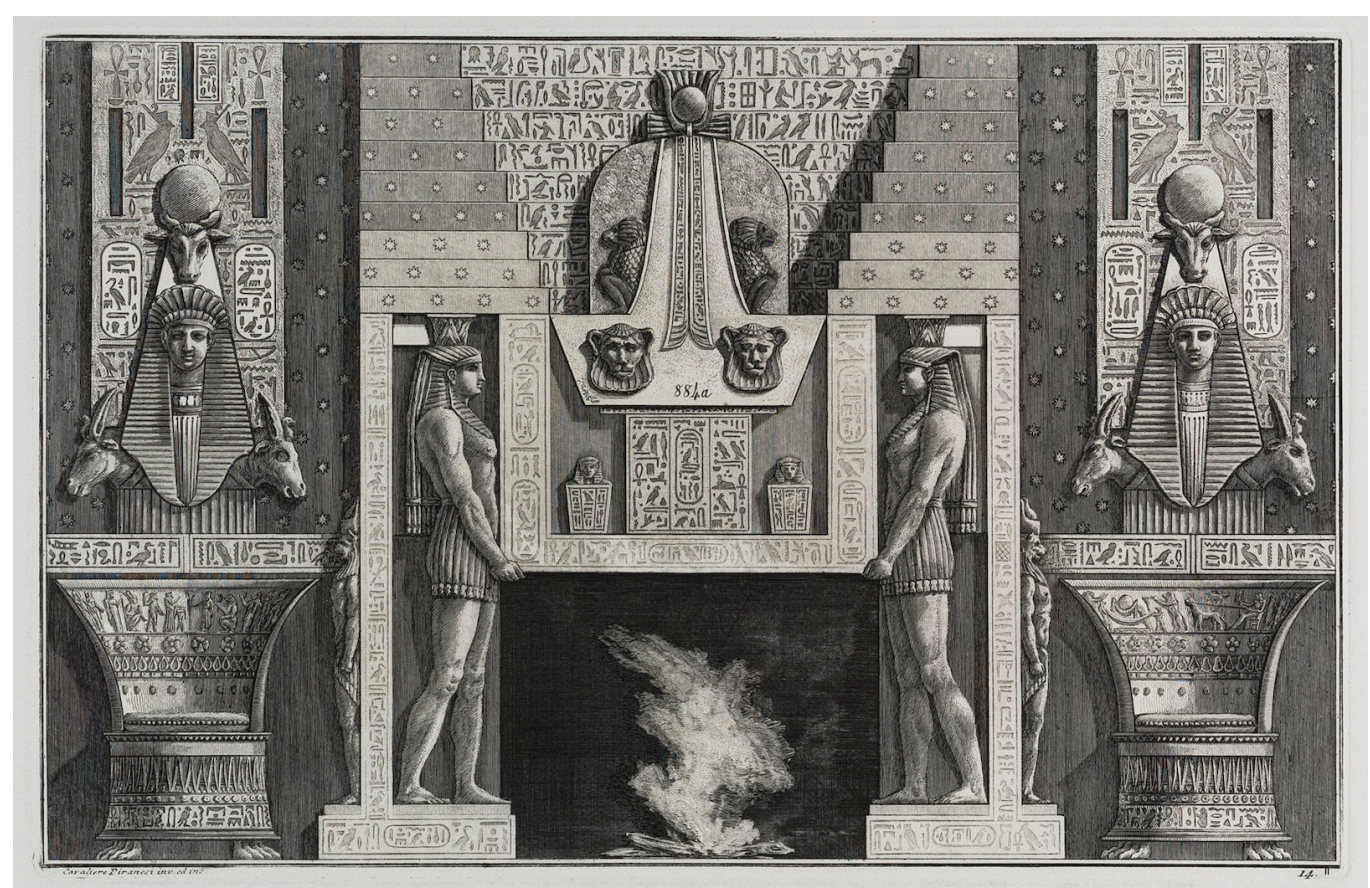

Fin dai primi racconti di viaggiatori tornati dalla Turchia a metà del XVI secolo, l'idea che nell'Antico Egitto si celassero radici magiche impenetrabili era forte e viva. La polvere di mummia era venduta come panacea e base per pozioni e sortilegi e, ancora a metà dell'ottocento, si trovano stampe popolari dove le sfingi sono rappresentate con volto di donna, per via dell'inveterata confusione con la Sfinge della mitologia greca (fig. 2).

Tuttavia, l'inizio della grande trasformazione dell'egittomania' in egittologia è normalmente considerato in coincidenza con l'esito del lungo lavoro di Champollion che, dopo quindici secoli di oblio, restituisce alla lettura - e allo studio - la grafia degli antichi (il geroglifico) e, più in generale, a quanto è stato prodotto nella Francia dei primi due decenni del XIX secolo. Nel frattempo, in ragione della presenza francese e poi inglese in Egitto, le antiche vestigia erano divenute oggetto di predazione: viaggiatori (non è possibile parlare di archeologi, piut- 
Fig. 2. J. Clark, Sphinx Stampa da incisione. Londra, 1735.

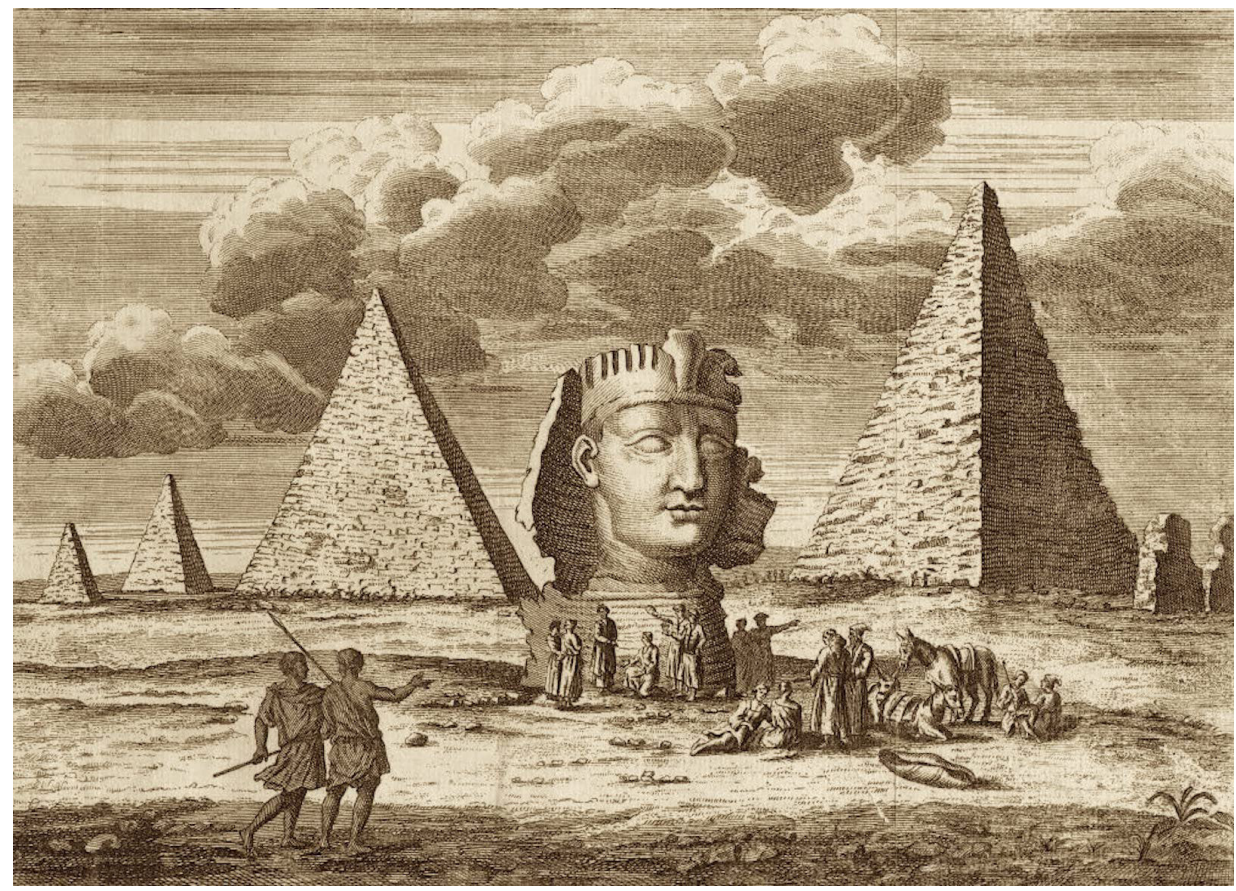

tosto di avventurieri) con pochi scrupoli di ordine metodologico, stavano riempiendo i depositi e le sale di tutti i musei d'Europa con opere d'arte egizia, costituendo collezioni tanto ricche quanto disparate e prive di valore archeologico in senso moderno. Parallelamente a questa disordinata disgregazione dei reperti materiali (e a suo parziale indennizzo), un contributo fondamentale nella direzione della nascita e dello sviluppo dei primi, numerosi, studi di carattere scientifico della cultura dell'antico Egitto, giunge dalla rappresentazione, in breve dal disegno. II resoconto di viaggio di Denon, ricchissimo di illustrazioni precise e attendibili (fig. 3) e, soprattutto, la pubblicazione di un'opera monumentale come la Description de l'Egypte hanno contribuito, quantomeno da principio, in maniera decisiva alla formazione nella consapevolezza degli uomini di scienza di una nuova 'disciplina' (figg. 4, 5).
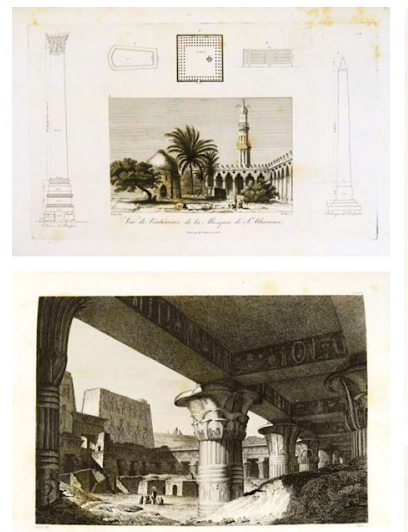

Fig. 3. D.V. Denon, Voyage dans la Basse et la Haute Égypte pendant les campagnes du généra avole

Fig. 4. Déscription de l'Egypte, Edition De Luxe,
Volume 2,Tavola XXIV. Parigi, 1821.
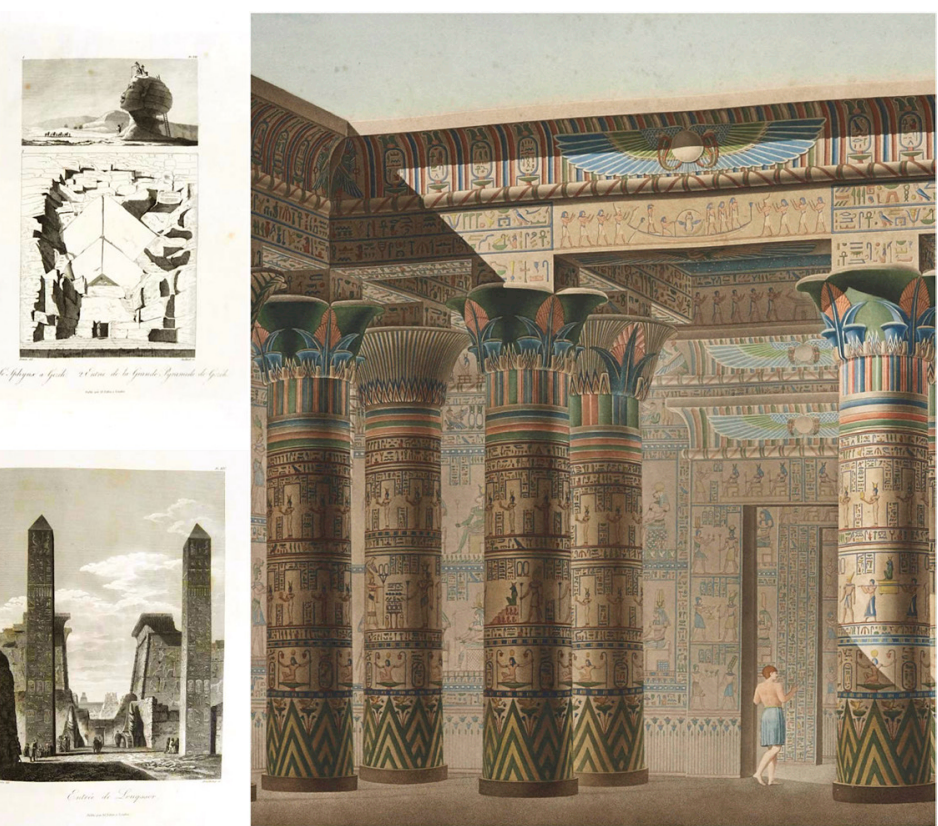
Fig. 5. Déscription de l'Egypte, Edition De Luxe, Volume 4,Pl. 72. Volume 5, PI. |4. Parigi, | $82 \mid$.Fig.

Fig. 6. F. A. Bridgman, The Procession of the Sacred Bull, Apis, Londra, c. 1879
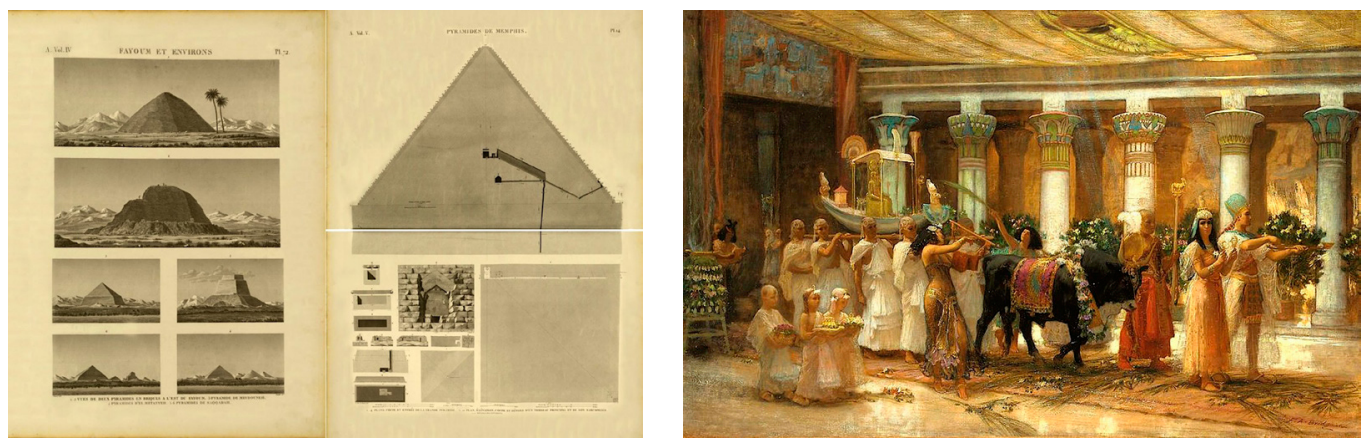

\section{II ruolo di Monge}

Quasi un anno esatto prima del ritrovamento della Stele di Rosetta, Napoleone dispone la requisizione del palazzo di Hassan-Kashif a II Cairo per insediare l'Institut d'Égypte. L'iniziativa non rappresenta un fatto isolato, il futuro Imperatore aveva un quadro molto preciso di quanto l'avanzamento culturale giovasse all'evoluzione dei popoli e, al tempo stesso, anche alla propria possibilità di avvalersi del sostegno degli ideologues, categoria di intellettuali post-rivoluzionari che era materialmente in grado di esercitare una forte influenza sulle scelte della politica repubblicana.

Era stato appunto nella cornice di queste relazioni che il 18 ottobre 1797, Bonaparte aveva affidato a Gaspard Monge, oltre che al Capo di Stato Maggiore della sua armata, il generale Berthier, l'incarico di tenere al Direttorio la relazione sul trattato di Campoformio.

Monge, nel 1797, aveva cinquantun anni e un solido passato a cavaliere tra la scienza e l'amministrazione dello stato. La Géométrie Descriptive, grazie alla quale aveva ottenuto ventiduenne la cattedra di matematica, era stata un ben custodito segreto militare pre-rivoluzionario ma l'adesione entusiastica all'insurrezione generale del 1789 l'aveva condotto, tre anni dopo, a ricoprire l'incarico di Ministro della Marina. E fu lo stesso Monge, in un sintetico rapporto, a proporre all'Institut National il generale Bonaparte in sostituzione di Lazare Carnot, suo stesso allievo all'Accademia Militare di Mézières, provvisoriamente rifugiato in Svizzera per le sfortunate conseguenze del putsch del 18 fruttidoro (4 settembre).

Con queste premesse, è facile capire come la struttura del Institut d'Egypte fosse ricalcata su quella dell'Institut de France, con Gaspard Monge come presidente.

Sotto la direzione diretta, ferrea ed entusiastica dello stesso Monge, fu quindi organizzata la redazione della Description.

Applicando alla campagna di rilievo i criteri di una campagna militare, Monge dispone nel novembre del I798, la costruzione di strumenti specifici: goniometri di precisione, longimetri, canne ad acqua e cannocchiali graduati.

L'Institut aveva perduto la propria dotazione per gli eventi bellici, parte nelle navi affondate da Nelson nella baia di Abu Qir ad agosto e parte durante la rivolta popolare de II Cairo,
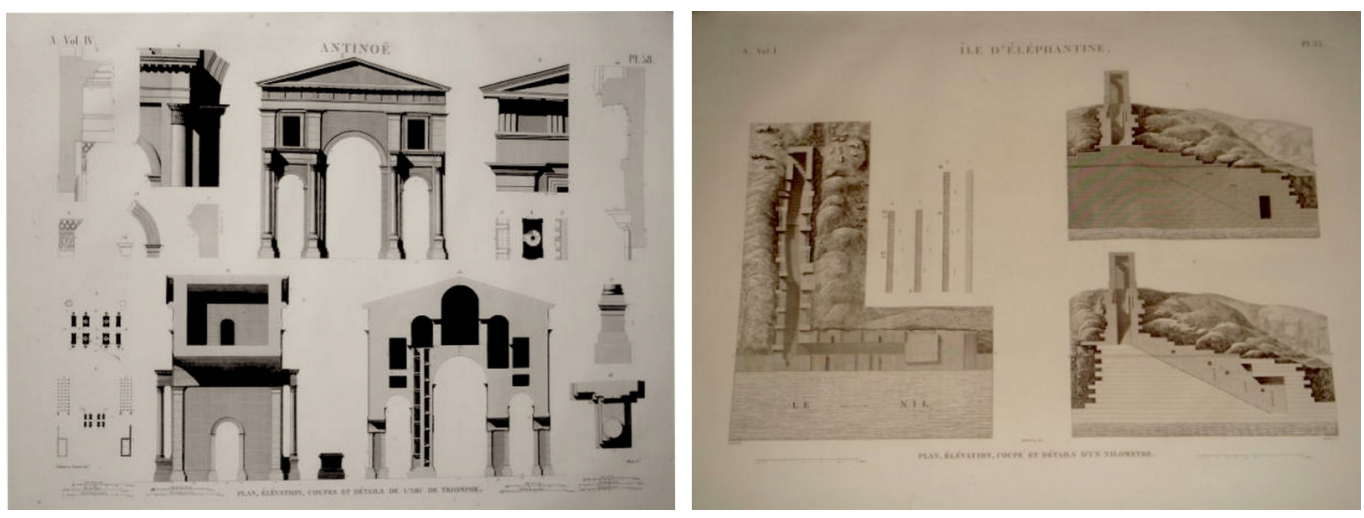
Fig. 8. Déscription de l'Egypte, Edition Impériale, Volume II, PI. 37. Parigi, 1809.

Fig. 9. Déscription de l'Egypte, Edition Impériale, Volume V, PI. 3. Parigi, I 809 due mesi dopo. Monge, tuttavia, colse l'occasione per progettarne e farne realizzare di migliori, secondo la logica di progresso tecnico che ormai da decenni aveva sostituito il conservativismo accademico nella valutazione dei maitre à penser.

L'Institute d'Egypte era nato con lo stesso obiettivo statutario del gemello francese, in sintesi, quello di sostenere e promuovere la diffusione della conoscenza. Ancora prima di iniziare la campagna di rilievo, Gaspard Monge organizza infatti, la pubblicazione di un giornale, il Courier d'Egypte e di una rivista, la Decade Egyptienne, che, oltre alla funzione di accentrare e ufficializzare l'informazione politica e, in un certo senso, anche militare, davano conto dell'attività svolta dalla Commission des Sciences et Arts d'Égypte e dallo stesso Institut.

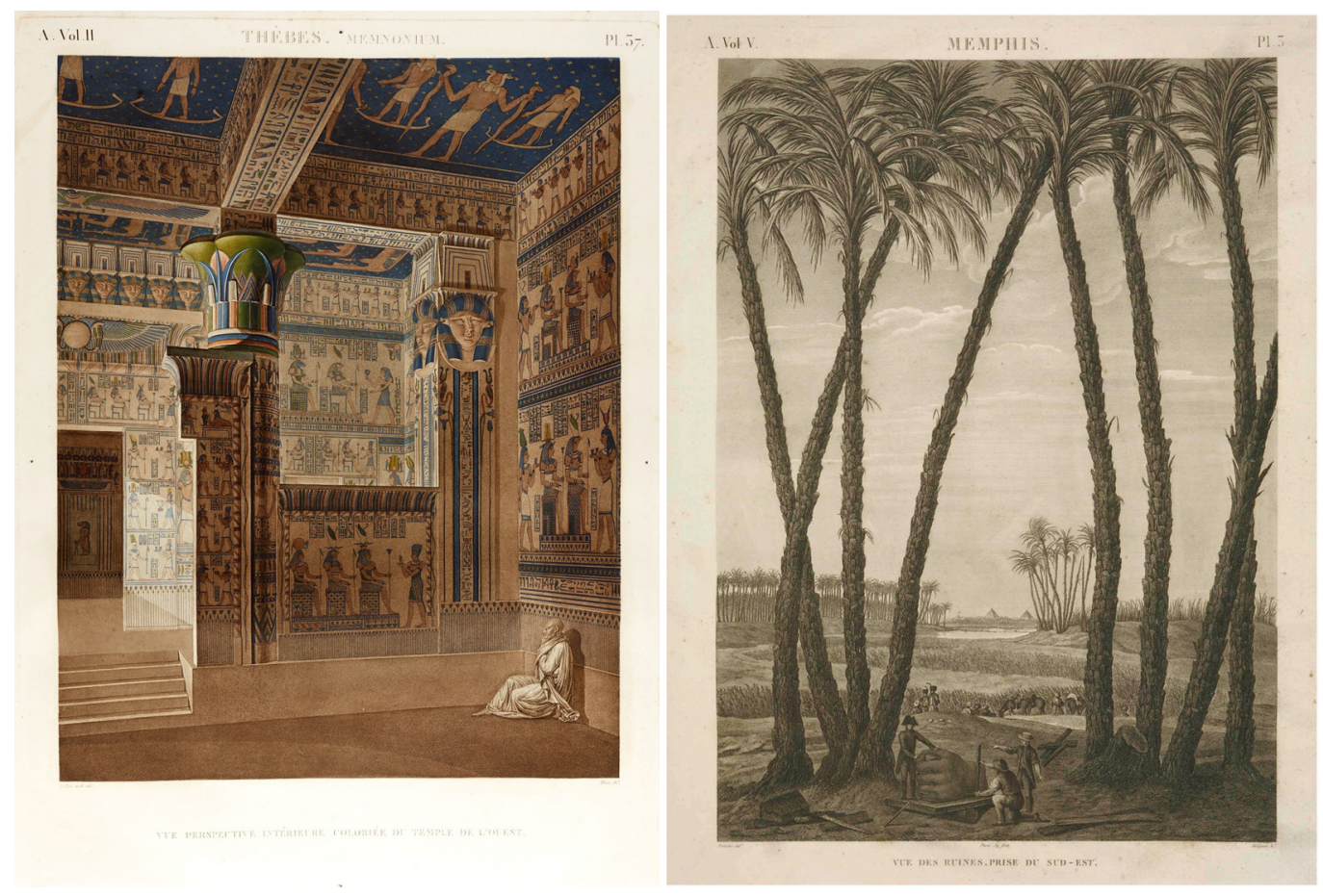

\section{L'Egitto come patria primigenia}

Alla redazione della Description, che inizia grossomodo con il 1799 , collaborano più di centocinquanta studiosi francesi. II dispiegamento di una così impressionante force de frappe si deve alla lungimiranza di Bonaparte e alla capacità organizzativa dello stesso Monge.

Ancora prima di partire per la campagna d'Egitto, Monge coinvolge quasi segretamente l'amico Claude Louis Berthollet, chimico di alto vaglio, già allievo di Lavoisier a Parigi, e politico rivoluzionario, nel reclutamento dei futuri membri della Commission des Sciences et des Arts che Bonaparte aveva in mente di portare con sé in Egitto.

Come aveva già ampiamente noto e dimostrato, durante la campagna d'Italia, Bonaparte era ben consapevole che il diretto coinvolgimento dei savants era fondamentale per trasformare un successo militare in un successo storico. Le studio delle racines culturelles dei popoli assoggettati (fig. 6), consolidava la relazione con l'invasore che, con una logica post-alessandrina, legittimava sé stesso anche agli occhi del mondo, come porteur de l'insigne. E quale luogo aveva più da rivelare, del misterioso Egitto?

Su questo punto, vediamo la possibilità che l'Egitto sia stato scelto dallo stesso Bonaparte come obiettivo militare, proprio per questo.

All'inizio del 1798, i generali Maximilian Caffarelli du Falga, Jean-Baptiste Kléber, Louis Desaix coordinati dallo stesso Bonaparte affrontano la sconvolgente, segretissima proposta del Direttorio di invadere l'Inghilterra. Giungono persino a viaggiare per settimane nel Nord della 
Francia e in Belgio, per prefigurare le linee dei rifornimenti, gli imbarchi e le riparazioni navali. Napoleone si presenta il 2 I di febbraio nell'aula del Direttorio e dichiara che l'invasione è possibile ma prematura. È in quell'occasione che avanza il suggerimento di una strategia erosiva ai danni dell'Impero Britannico, proponendo furbamente due obiettivi, dei quali uno particolarmente ostico, per la vicinanza con il suolo francese e la durezza del nemico. II Direttorio, prevedibilmente, ritiene che attaccare l'Hannover, luogo di origine genealogica della casa regnante inglese (Sassonia-Coburgo-Gotha, poi ufficialmente mutata nel 1917 in Windsor, per stemperare la popolare ostilità antigermanica, nel corso della Prima Guerra Mondiale) sia troppo rischioso e ripiega proprio dove il generale Bonaparte voleva arrivare. II Direttorio deliberò quindi di agire in Egitto, dove l'autorità dell'Impero Ottomano traballava, non riuscendo più a controllare il territorio con gli ormai decaduti Mamelucchi, e I'Inghilterra intratteneva rapporti commerciali particolarmente proficui. A sostenere questa decisione hanno certamente contribuito i rapporti di Charles Magallon, console della Repubblica ad Alessandria, rapporti che Talleyrand aveva in mano dal 9 febbraio. Magallon, nei dispacci, disegnava un quadro di estrema, quasi eccessiva, facilità militare e, a questo proposito, riteniamo che Bonaparte, sulla scorta dell'esperienza fatta durante la campagna d'Italia, possa aver strategicamente influenzato tanto la redazione dei contenuti, quanto lo straordinariamente tempestivo invio al Direttorio, precedente di una sola settimana la sua relazione del 21 febbraio 1798.

"Bonaparte veut se présenter, avec le force des concepts nouveaux, comme le héros civilisateur par excellence. Son programme de civilisation en marche se fonde sur l'idée inlassablement reprise que l'expédition en Égypte est le retour des sciences et des arts dans leur patrie d'origine" [Laurens 1989, p. 31].

Fig. 10. Déscription de l'Egypte, Edition Impériale Volume V. Pl. I I. Parigi, 1809

Fig. I I. Déscription de l'Egypte, Edition Impériale, Volume III, PI. 6. Parigi, 1809.
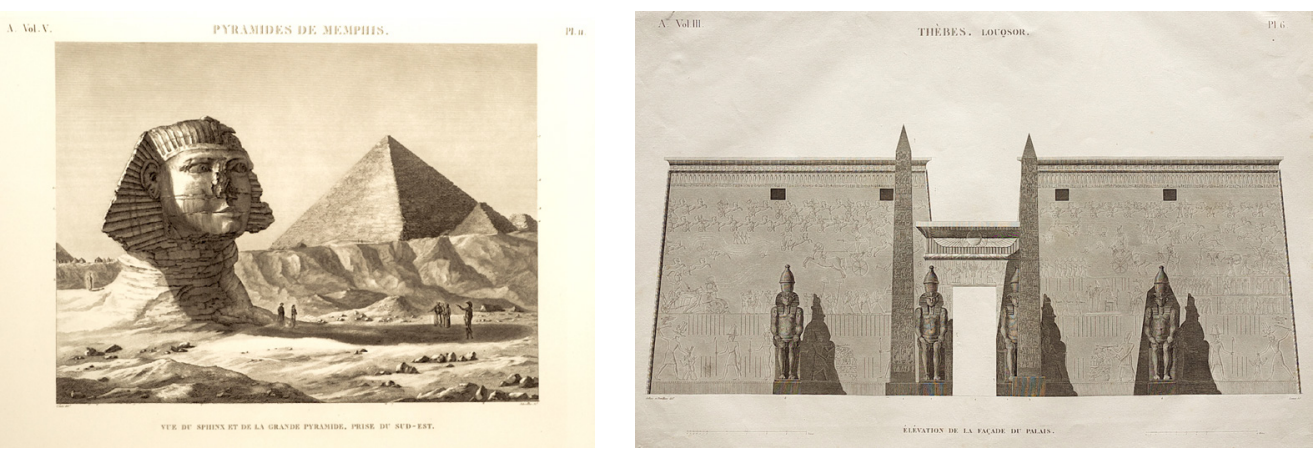

\section{Conclusioni}

La campagna coordinata dall'Institut e la pubblicazione dei relativi resoconti grafici rappresentano la più grande affermazione della campagna napoleonica in Egitto.

Nei grossomodo due anni (|799- | 80 I) di attività sul campo fu raccolto materiale sufficiente per l'impianto praticamente da zero di una disciplina nuova: l'egittologia. Questo straordinario successo scientifico è da ascrivere storicamente alla lucida volontà di Bonaparte e tecnicamente all'azione determinata e proficua di Gaspard Monge. L'applicazione rigorosa dei metodi della Géometrie Descriptive, oggetto di serratissime classi nel palazzo Hassan-Kashif, ha dato luogo a una ciclopica opera nella quale l'omogeneità dei codici e la qualità del dettaglio hanno di fatto indicato gli standard della rappresentazione per l'archeologia tutta (figg. 7, 8).

E particolarmente significativo notare come l'idea di una pubblicazione che contenesse ogni scoperta francese in Egitto sia stata pubblicamente esplicitata nel novembre 1798 da Joseph Fourier: questo rappresenta l'esito di un processo decisionale necessariamente più ampio, iniziato qualche mese prima, riteniamo già alla fine di febbraio, dopo la risoluzione del Direttorio di assecondare la proposta di Bonaparte per una campagna d'Egitto. 
La tradizionale data del febbraio I802, quella dell'emissione del decreto di Napoleone per costituzione di una singola pubblicazione di esprit enciclopédique che presentasse l'enorme mole di materiale raccolto sembra quindi da intendere come l'inizio del processo che conduce alla realizzazione pratica ma non come l'inizio del progetto generale della Description. Esso è da anticipare a prima della stessa partenza delle truppe e a noi sembra debba essere ritenuto ragionevolmente coevo alla stessa delibera del Direttorio che decide la Campagna. La richiesta di Jean-Antoine Chaptal per la formazione di una Commission Spéciale non è quindi un'idea indipendente ma è parte di un processo che, nella luce della storia, trasforma la il senso prevalente della Campagne d'Egypte da militaire a scientifique.

Il procedimento seguito per la compilazione di volumi mostra altresì una pianificazione a priori. Le ricerche già pubblicate sul Courier, sulla Decade e soprattutto nelle allegate Mémoires sul l'Egypte erano state indirizzate da Gaspard Monge, che interpretava la propria carica di Presidente dell'Institut in modo tutt'altro che onorario ed esercitava un pieno potere di controllo, verso la produzione di materiale omogeneo e interconnesso.

Cionondimeno il processo fu oneroso e mastodontico e l'edizione finale nel formato mammutfolio di I000×80 I mm (talora chiamato éléphant) raccoglie la rappresentazione in forma di modello geometrico e visivo della quasi totalità dei siti archeologici allora noti (figg. 9- I I) e di molte delle presenze architettoniche significative (fig. I2). Esso rappresenta il vero grande imperituro successo della Campagne d'Egypte.

Fig. 12. Déscription de l'Egypte, Edition Mammuth Volume I, PI. 38 - Pl. 28. Parigi, 1809.

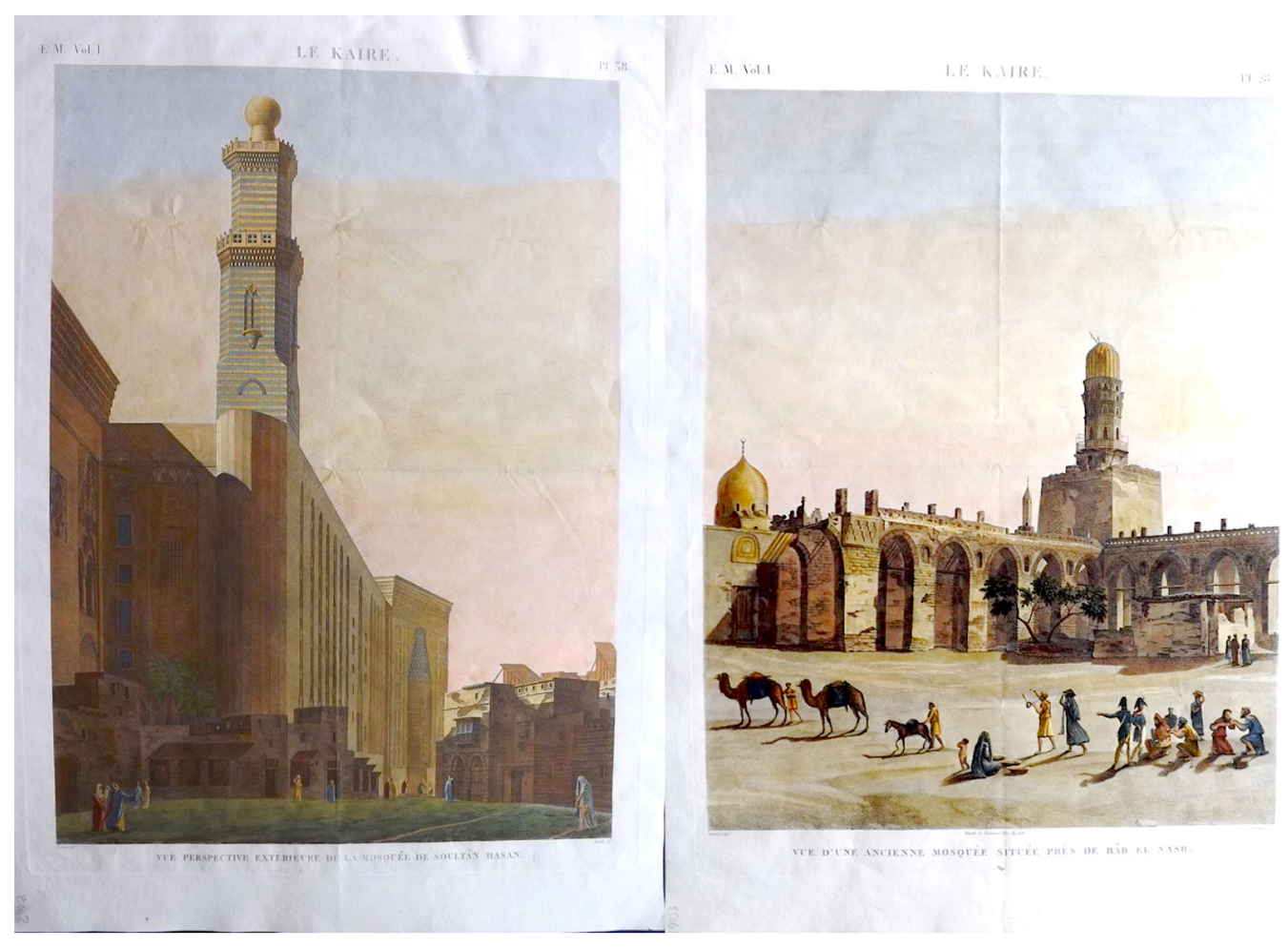

Note

[I] Si pensi, a titolo esemplificativo, al volume Augusta Taurinorum del 1577 che fa risalire a un'improbabile origine egizia la stessa città piemontese. Opera tutt'altro che secondaria, se si nota come Emanuele Tesauro, pochi decenni dopo, scrivendo la Historia della Augusta Città di Torino, ribadisce e sottolinea le (immaginarie) radici egizie di casa Savoia.

[2] Un esempio della funzione sostanzialmente esotica dell'Egitto ci è data dall'opera teatrale di Mozart II flauto magico ( I 79 | ). Il culto della civiltà egizia era ancora un fenomeno di massa. 


\section{Riferimenti bibliografici}

AA.W. (1809-1822). Description de l'Égypte ou recueil des observations et des recherches qui ont été faites en Égypte pendant l'expédition de l'armée française, publiée par les ordres de S.M. l'Empereur Napoléon. Paris: Imprimerie Impériale.

Aubry P.V. (1954). Monge, le savant ami de Napoléon: I 746- I 8 I 8. Paris: Gauthier-Villars. In De Launay, L. (ed.) (I933). Un grand français: Monge, fondateur de l'École Polytechnique. Paris: Roger.

Denon D.V. ( 1 802). Voyage dans la Basse et la Haute Égypte pendant les campagnes du Général Bonaparte. Paris: Imprimerie de P. Didot.

Gillespie C. C. (1989). Aspects scientifiques de l'Expédition d'Égypte (|798-|80 I). In Laurens H. (ed.). L'expédition d'Égypte 1798-1801. Paris: Colin, pp. 37|-396.

Humbert J., Pantazzi M. M., Ziegler C. (1994). Egyptomania: L'Égypte dans l'art occidental: I 730- 1 930, Paris, Louvre, 20 jan- 8 avr. Catalogue. Paris: R. M. N.

Laissus Y. (1960). Gaspard Monge et l'expédition en Égypte (I798- I799). In Revue de Synthèse, vol. XIX-XX, pp. $309-336$.

Laurens H. ( 1988). Bonaparte, l'Orient et la Grande Nation. In Annales Historiques de la Révolution Française, n. 273, pp. 289-30 I.

Pepe L. (1996). Gaspard Monge in Italia: La formazione e i primi lavori dell'Istituto Nazionale della Repubblica Romana. In Bollettino di storia delle scienze matematiche, n. 16, pp. 45-100.

Taton R. (I95I). L'oeuvre scientifique de Gaspard Monge. Paris: P.U.F.

Vercoutter J. (1998). À la recherche de l'Égypte oubliée. Paris: Gallimard.

Wassef A.S. (1975). L'information et la presse officielle en Égypte jusqu'à la fin de l'occupation française. Le Caire: I.F.A.O.

\section{Autore}

Daniele Giovanni Papi, Politecnico di Milano, daniele.papi@polimi.it

Per citare questo capitolo: Papi Daniele Giovanni (202I). La campagna d'Egitto: il contributo essenziale di Bonaparte e Monge alla moderna egittologia/The Egypt Campaign: the essential contribution of Bonaparte and Monge to modern egyptology. In Arena A., Arena M., Mediati D. Raffa P. (a cura di). Connettere. Un disegno per annodare e tessere. Linguaggi Distanze Tecnologie. Atti del $42^{\circ}$ Convegno Internazionale dei Docenti delle Discipline della Rappresentazione/Connecting. Drawing for weaving relationship. Languages Distances Technologies. Proceedings of the $42^{\text {th }}$ International Conference of Representation Disciplines Teachers. Milano: FrancoAngeli, pp. $1780-1795$. 


\title{
The Egypt Campaign: the Essential Contribution of Bonaparte and Monge to Modern Egyptology
}

\author{
Daniele Giovanni Papi
}

Abstract

On July 15, 1799, during the repair work of Fort Julien, in the city of Rosetta, on the Nile delta (today's Rashid), a private soldier who remained anonymous, under the orders of Captain Pierre Bouchard, found himself facing a block of black basalt covered with inscriptions. The surface was divided into three sectors: a long hieroglyphic sequence, a text in ancient Demotic and one in Greek. By order of General Jacques François Menou, the stele was transported to Alexandria and entrusted to some classicists who were following the Napoleonic expedition. They began the translation of the part into Greek (abandoned, then resumed, finally completed in 1803), a decree of Ptolemy $\mathrm{V}$, and imagined that the demotic and hieroglyphic text were the transcription.

It took two decades but, in 1822, Jean François Champollion, who had the contact copies that the Commission des Sciences et des Arts had made before, in 1801 , the stele was merged with the spoils of war that the British demanded, after the defeat of Napoleon, he managed to deci-pher the hieroglyphic characters.

The Western cultural tradition traces this to the beginning of modern Egyptology, however we believe that it is possible to evaluate events in a slightly different way and to argue that at least one battle for drawing has been consciously supported in history.

Keywords

Monge, Egypt, Napoleon, Archaeology, Campaign
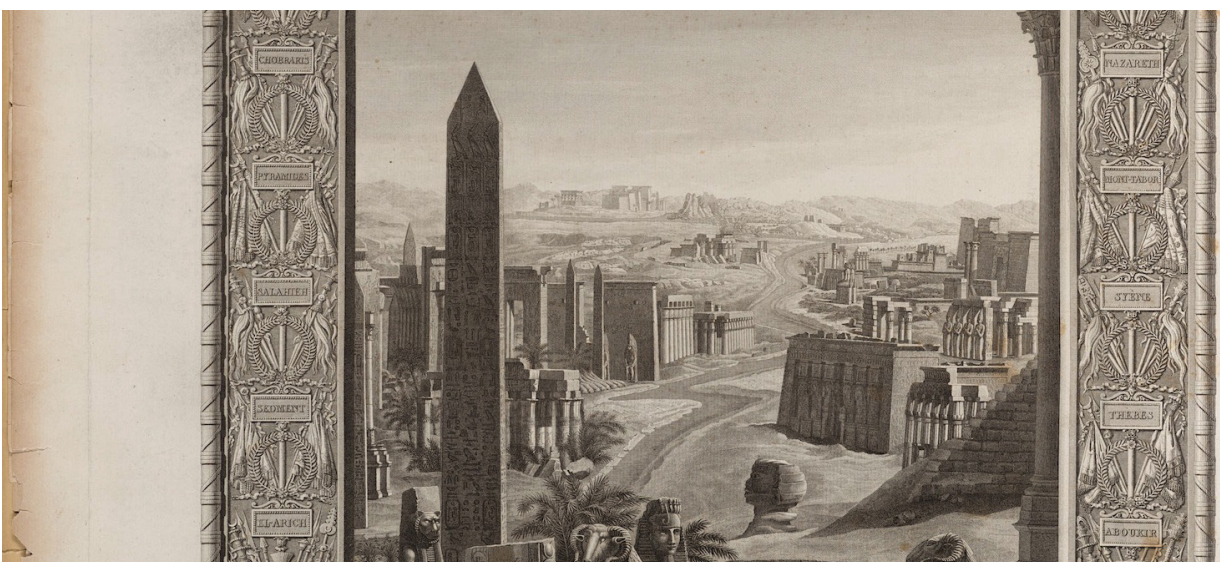


\section{Egypt, myth and history}

Starting from the sixteenth-century discovery of a statue of Isis in the subsoil of Turin, a form of growing curiosity towards everything that was Egyptian gradually invaded Europe.

This interest grew until the whole of the eighteenth century, when we can speak of the first real Egyptomania (the second will be in the 20s of the twentieth century after the discovery of Howard Carter who violates the tomb of Tut-Ankh-Amon). In the course of the 18th century, traditionally through the contribution of Winkelmann, collecting tends to become archaeology and the first scientific questions begin to be asked. The analytical and methodological instances slowly take the place of what had been, up to that point, essentially a phenomenon of custom [I].This, obviously, does not abruptly place order in the consideration of the finds and testimonies linked to the ruins but represents an awareness of Western civilization towards the past.

Giovan Battista Piranesi himself, in 1769, published the Diverse maniere di adornare i Cammini, a volume rich in decorations explicitly referred to as alla egizia. (fig. I ) [2]

We can well imagine how the mystery hidden in the indecipherable hieroglyphs, often traced back to the symbolic role of magical inscriptions rather than to that of actual writing, contrasted the turn towards analytic study.

Fig. I. G.B. Piranesi, Diverse maniere di adornare $\mathrm{i}$ cammini, Table 14 . Rome, 1769.

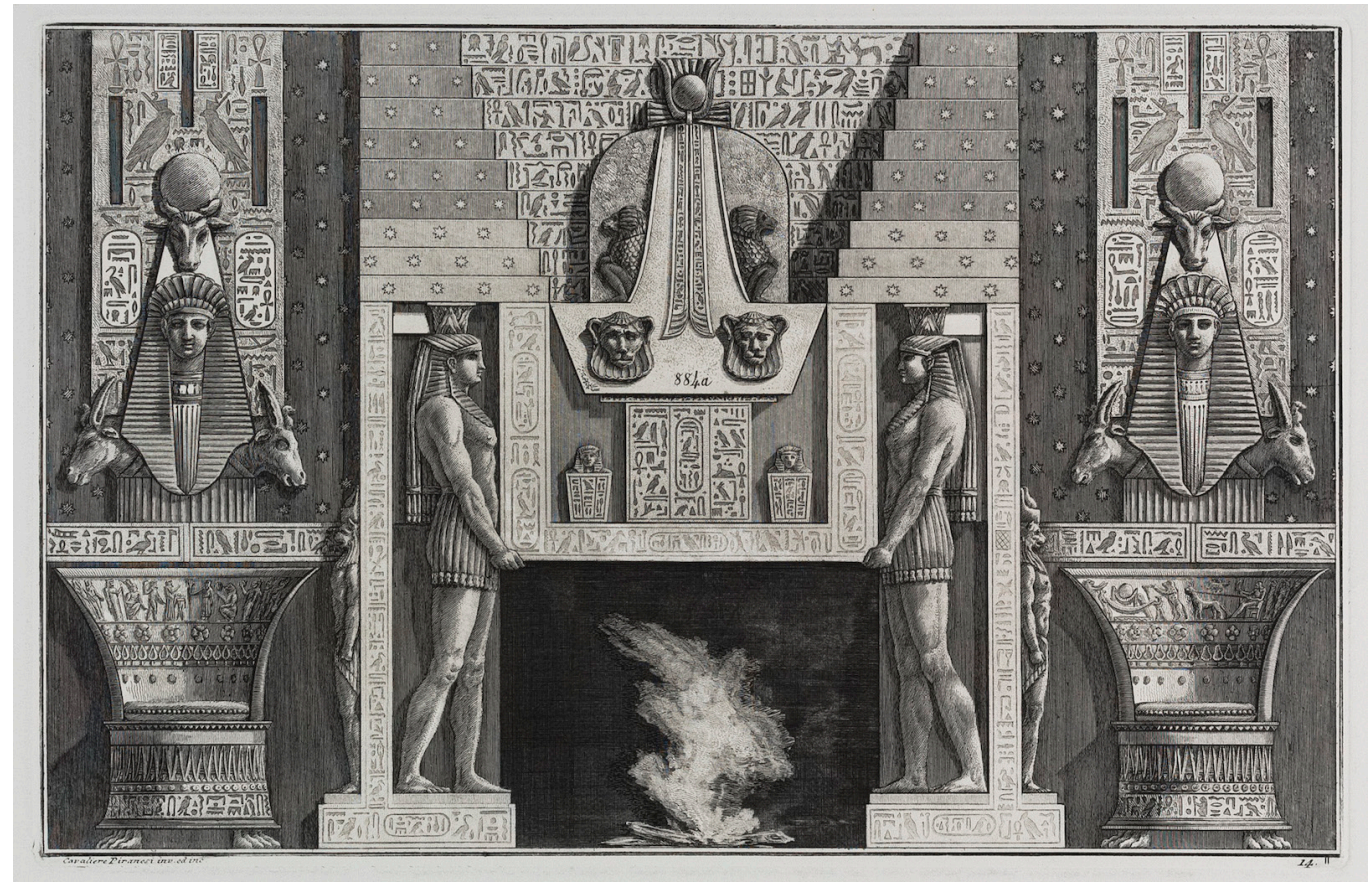

From the earliest stories of travellers returning from Turkey in the mid- I 6th century, the idea that impenetrable magical roots were hidden in Ancient Egypt was strong and alive. Mummy dust was sold as a panacea and base for potions and spells and, still in the mid-nineteenth century, there are popular prints where the sphinxes are represented with a woman's face, due to the inveterate confusion with the Sphinx of Greek mythology (fig. 2).

However, the beginning of the great transformation of Egyptomania into Egyptology is normally considered to coincide with the outcome of Champollion's long work who, after fifteen centuries of oblivion, returns to reading -and studying- the handwriting of the ancients (the hieroglyph) and, more generally, to what was produced in France in the first two decades of the nineteenth century.

Meanwhile, due to the French and then English presence in Egypt, the ancient vestiges had become objects of predation: travellers (it is not possible to speak of archaeologists, rather 
Fig. 2. J. Clark, Sphinx, engraving print. London, 1735

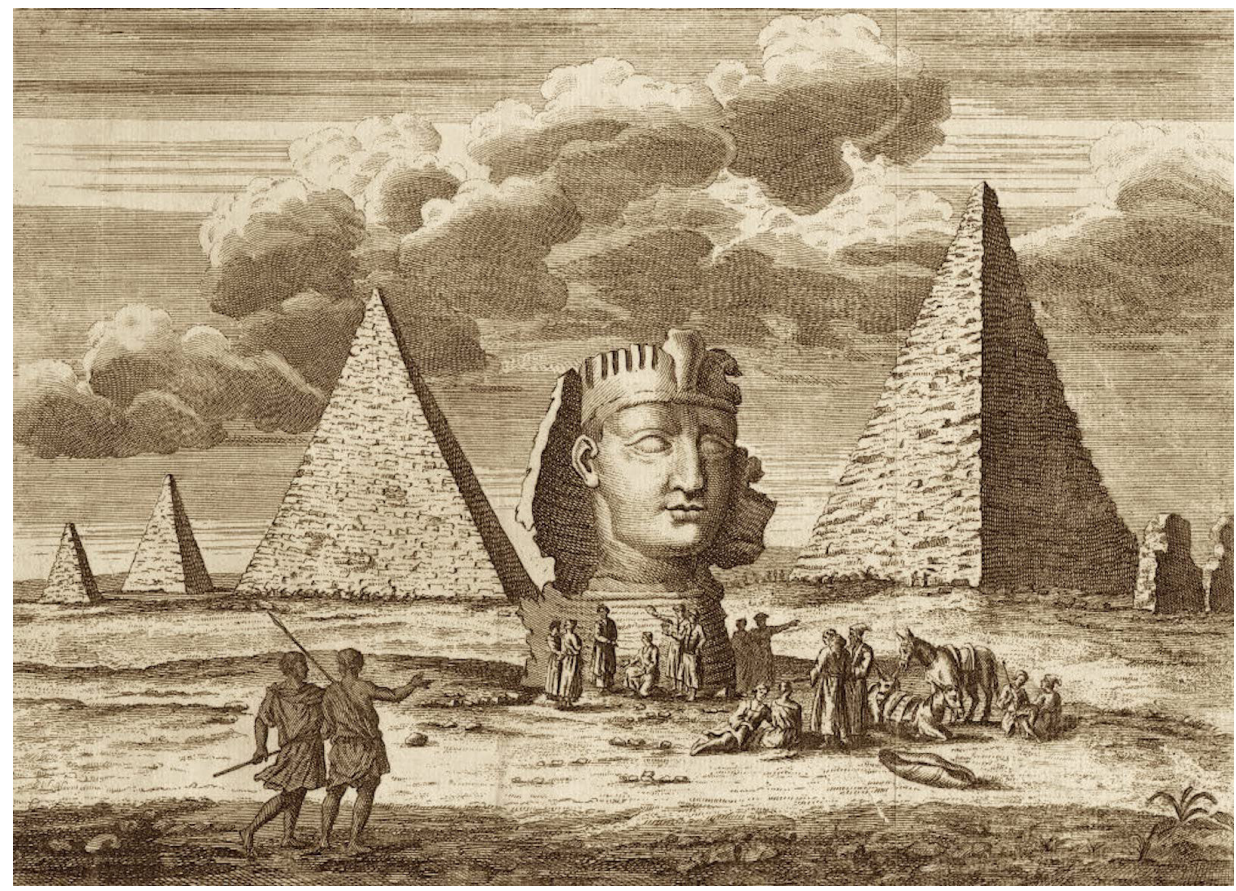

of adventurers) with few methodological scruples, were filling the deposits and exposition galleries of all the museums of Europe with Egyptian works of art, forming collections as rich as they are disparate and without archaeological value in the modern sense. Parallel to this disordered disintegration of the material finds (and to its partial compensation), a fundamental contribution in the direction of the birth and development of the first, numerous, scientific studies of ancient Egyptian culture, comes from representation, in short from drawing. Denon's travel report, very rich in precise and reliable illustrations (fig. 3) and, above all, the publication of a monumental work such as the Description de l'Egypte contributed, at least from the beginning, in a decisive way to the formation in the awareness of men of science of a new 'discipline' (figs. 4, 5).
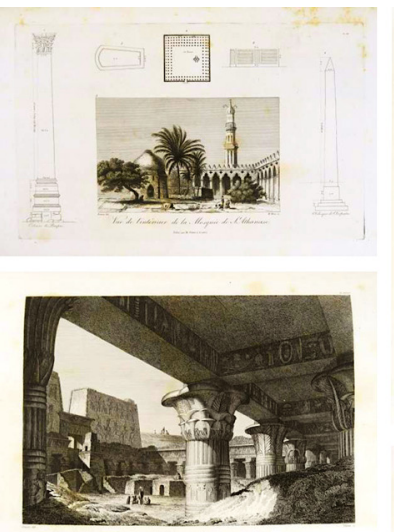

Fig. 3. D.V. Denon, Voyage dans la Basse et la Haute Égypte pendant les campagnes du généra text. Paris, 1802

Fig. 4. Déscription de l'Egypte, Edition De Luxe Volume 2,Tab. XXIV. Paris, |821.
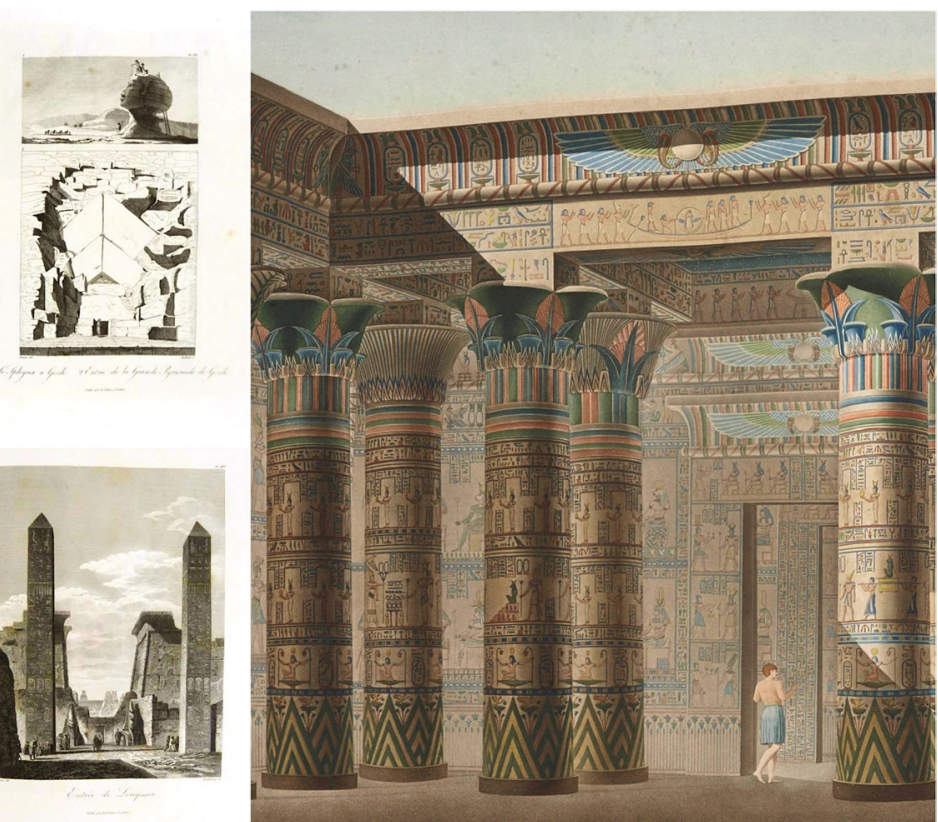
Fig. 5. Déscription de l'Egypte, Edition De Luxe. Volume 4, PI. 72. Volume 5, PI. |4. Paris, $|82|$

Fig. 6. F. A. Bridgman, The Procession of the Sacred Bull, Apis, London, around 879
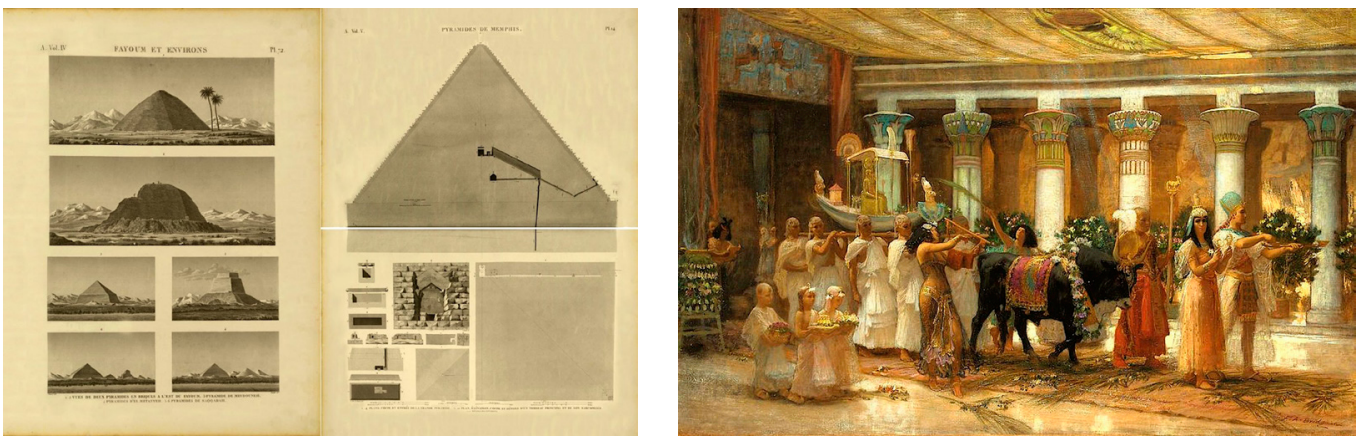

\section{The role of Monge}

Almost exactly one year before the discovery of the Rosetta Stone, Napoleon ordered the requisition of the palace of Hassan-Kashif in Cairo to establish the Institut d'Égypte. The initiative does not represent an isolated event, the future Empereur had a very precise picture of how much cultural advancement benefited the evolution of peoples and, at the same time, also to his own possibility of availing himself of the support of ideologues, a category of post-revolutionaries who were physically able to exert a strong influence on the choices of republican politics.

It was precisely in the framework of these reports that on 18 October 1797, Bonaparte had entrusted Gaspard Monge, as well as the Chief of Staff of his army, General Berthier, with the task of keeping the report on the treaty of Campoformio in the Directorate.

Monge, in 1797, was fifty-one years old and had a solid past as a knight between science and state administration. The Géométrie Descriptive, thanks to which he had obtained the chair of mathematics at only twenty-two, had been a well-kept pre-revolutionary military secret but the enthusiastic adherence to the general uprising of 1789 had led him, three years later, to cover the post of Minister of the Navy. And it was Monge himself, in a brief report, who proposed General Bonaparte to the Institut National to replace Lazare Carnot, his own pupil at the Military Academy of Mézières, who had temporarily taken refuge in Switzerland due to the unfortunate consequences of the putsch of 18 Fructidoro (September 4).

With these premises, it is easy to understand how the structure of the Institut d'Egypte was modelled on that of the Institut de France, with Gaspard Monge as president.

Under the direct, iron and enthusiastic direction of Monge himself, the drafting of the 'Description' was organized.

Applying the criteria of a military campaign to the survey campaign, Monge ordered the construction of specific instruments in November 1798: precision goniometers, longimeters, water level pipes and graduated telescopes.

The Institut had lost its equipment due to war events, partly in the ships that Nelson sank in Abu Qir bay in August and partly during the popular uprising in Cairo, two months later.
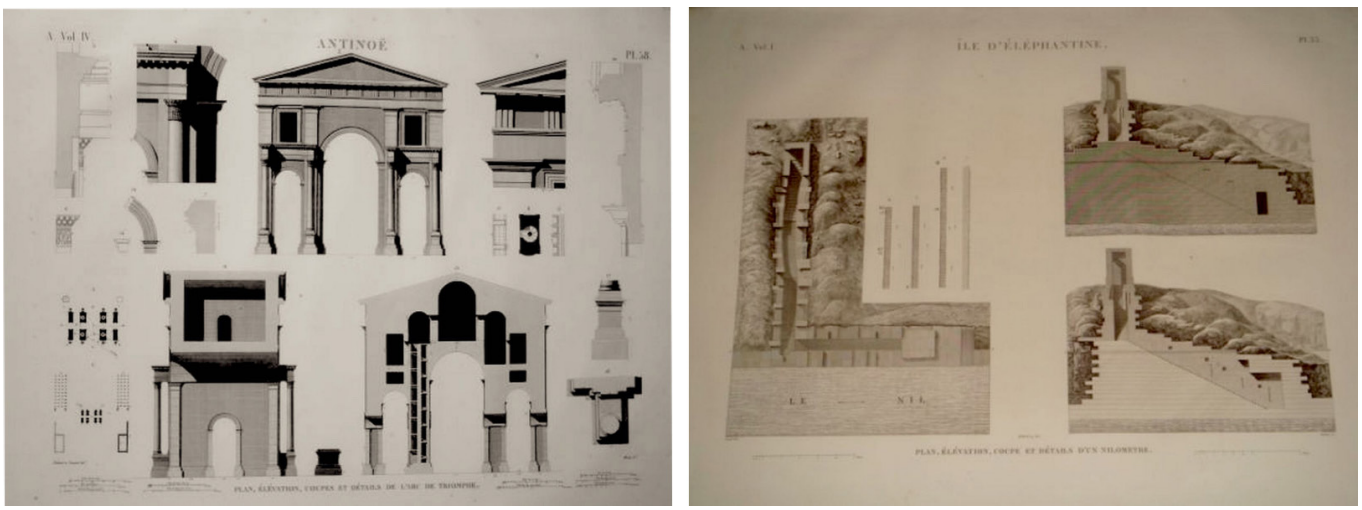
Fig. 8. Déscription de l'Egypte, Edition Impériale, Volume II, PI 37. Paris, 1809.

Fig. 9. Déscription de 'Egypte, Edition Impériale, Volume V, PI. 3. Paris, 1809
Monge, however, took the opportunity to design and build better ones, according to the logic of technical progress that for decades had replaced academic conservatism in the evaluation of maitre à penser.

The Institut d'Egypte was born with the same statutory objective as the French twin, in short, that of supporting and promoting the dissemination of knowledge. Even before starting the major survey campaign, Gaspard Monge organized the publication of a newspaper, the Courier d'Egypte and a magazine, the Decade Egyptienne, which, in addition to the function of centralizing and formalizing political information and, in a certain sense, even military, accounted for the activity carried out by the Commission des Sciences et Arts d'Égypte and by the Institut itself.

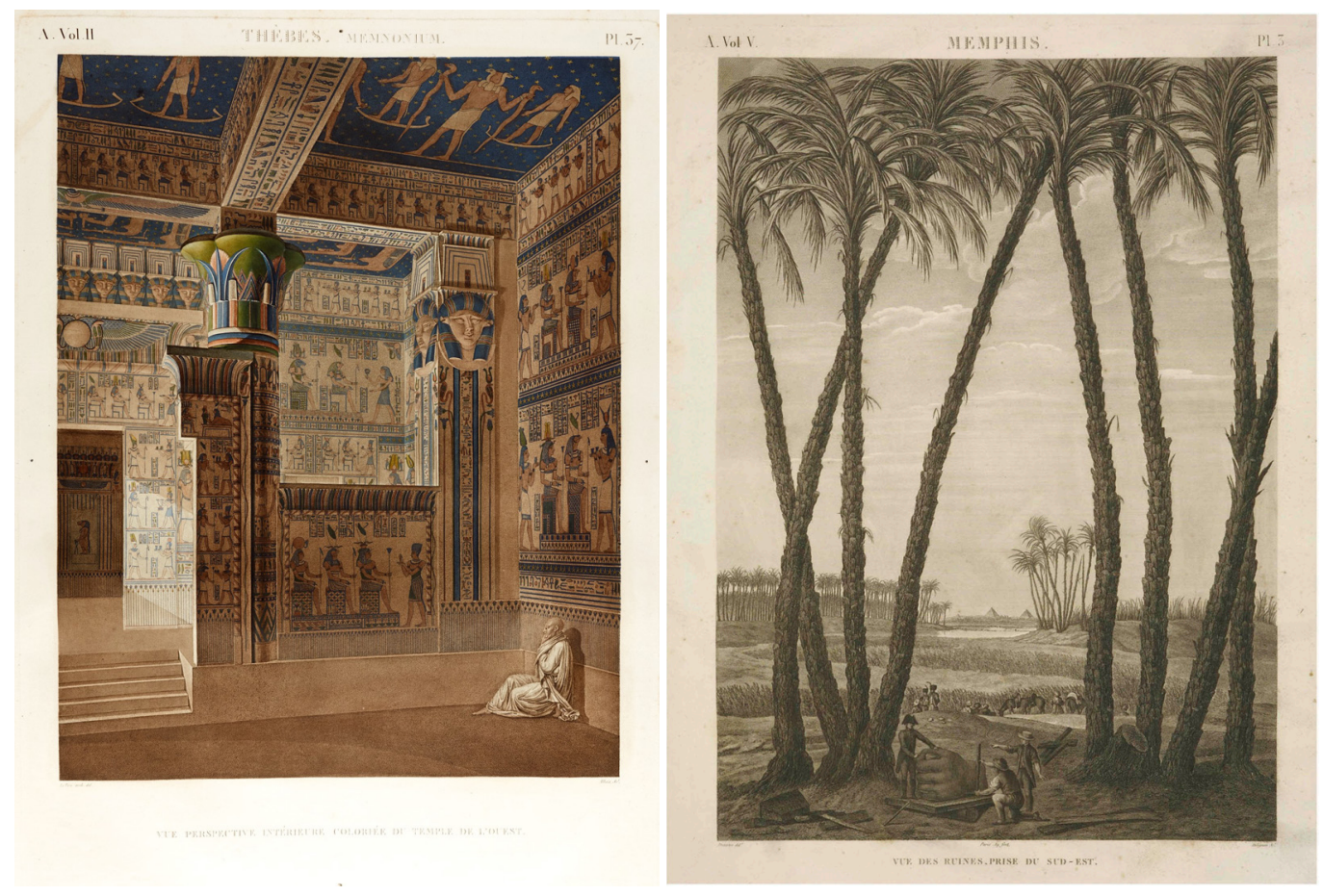

\section{Egypt as a primeval homeland}

More than one hundred and fifty French scholars collaborate on the drafting of the Description, which roughly begins in 1799. The deployment of such an impressive force-de-frappe is due to Bonaparte's foresight and to the organizational capacity of Monge himself.

Even before leaving for the Egyptian campaign, Monge almost secretly involves his friend Claude Louis Berthollet, a highly rated chemist, former student of Lavoisier in Paris, and revolutionary politician, in the recruitment of future members of the Commission des Sciences et des Arts that Bonaparte had in mind to take with him to Egypt.

As he had already widely known and demonstrated, during the Italian campaign, Bonaparte was well aware that the direct involvement of the savants was essential to transform a military success into a historic success. The study of the racines culturelles of the subjugated peoples (fig. 6) consolidated the relationship with the invader who, with a post-Alexandrian logic, legitimized himself even in the eyes of the world, as a porteur de l'insigne. And what place had more to reveal than mysterious Egypt?

On this point, we see the possibility that Egypt was chosen by Bonaparte himself as a military target, precisely for this reason.

At the beginning of 1798, the generals Maximilian Caffarelli du Falga, Jean-Baptiste Kléber, Louis Desaix coordinated by Bonaparte himself faced the shocking, very secret proposal of the Directorate to invade England. They even travel for weeks in the north of France and 
Belgium, to foreshadow supply lines, shipments and ship repairs. Napoleon shows up on February $2 \mathrm{I}$ in the chamber of the Directorate and declares that the invasion is possible but premature. It is on that occasion that he advances the suggestion of an erosive strategy against the British Empire, cleverly proposing two objectives, one of which is particularly difficult, due to the proximity to French soil and the toughness of the enemy. The Directorate, predictably, believes that attacking Hanover, the place of genealogical origin of the English ruling house (Sachsen-Coburg-Gotha, then officially changed in 1917 to Windsor, to temper the popular anti-German hostility, during the First World War) was too risky and falls back exactly where General Bonaparte wanted to arrive.

The Directorate therefore decided to act in Egypt, where the authority of the Ottoman Empire was wavering, no longer able to control the territory with the now decayed Mamluks, and England had particularly profitable commercial relations. The reports of Charles Magallon, consul of the Republic in Alexandria, certainly contributed to this decision, reports that Talleyrand had in hand since February 9. Magallon, in the dispatches, drew a picture of extreme, almost excessive, military ease and, in this regard, we believe that Bonaparte, on the basis of the experience gained during the Italian campaign, may have strategically influenced both the drafting of the contents and the extraordinarily timely sending to the Directorate, preceding his report of February 2I, I 798 by only one week.

"Bonaparte veut se présenter, avec la force des concepts nouveaux, comme le héros civilisateur par excellence. Son programme de civilisation en marche se fonde sur l'idée inlassablement reprise que l'expédition en Égypte est le retour des sciences et des arts dans leur patrie d'origine" [Laurens 1989, p. 31].

Fig. 10. Déscription de l'Egypte, Edition Impériale 1809.

Fig. I I. Déscription de l'Egypte, Edition Impériale, Volume III, PI. 6. Paris, 1809
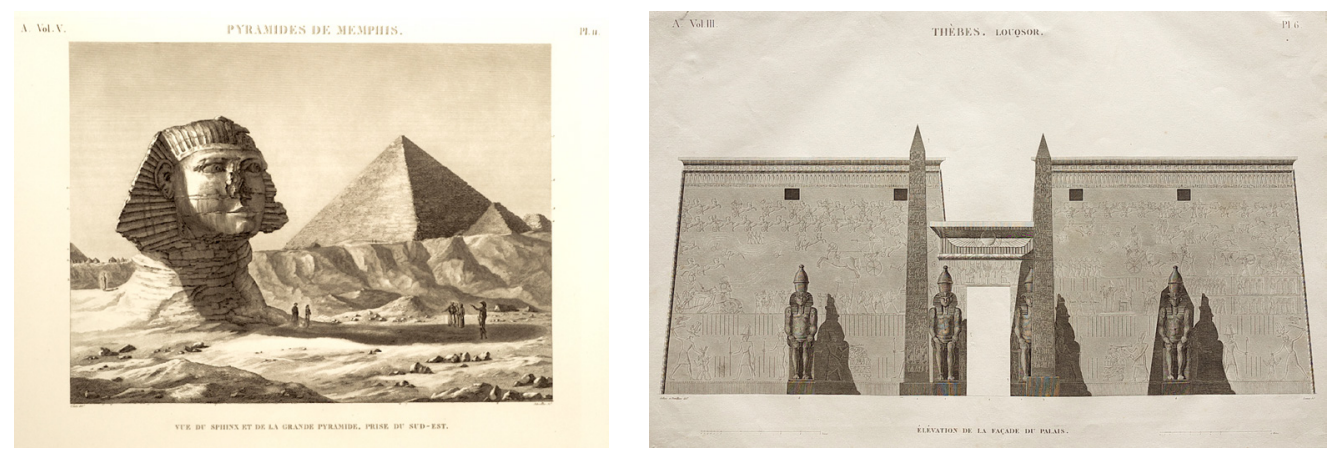

\section{Conclusions}

The campaign coordinated by the Institut and the publication of the related graphic reports represent the greatest success of the Napoleonic campaign in Egypt.

In roughly two years (I799-I80 I) of activity in the field, enough material was collected for the implantation of a new discipline practically from scratch: Egyptology. This extraordinary scientific success is historically to be ascribed to Bonaparte's lucid will and technically to the determined and profitable action of Gaspard Monge. The rigorous application of the methods of the Géometrie Descriptive, the subject of very tight classes in the Hassan-Kashif palace, has given rise to a gigantic work in which the homogeneity of the codes and the quality of the detail have in fact indicated the standards of representation for the whole archaeology (figs. 7,8).

It is particularly significant to note how the idea of a publication containing every French discovery in Egypt was publicly made explicit in November 1798 by Joseph Fourier: this represents the outcome of a necessarily broader decision-making process, which began a few months earlier, we believe already to the end of February, after the resolution of the Directorate to go along with Bonaparte's proposal for a campaign in Egypt. 
The traditional date of February 1802, that of the issuance of Napoleon's decree for the constitution of a single publication of esprit enciclopédique presenting the enormous amount of material collected therefore seems to be understood as the beginning of the process that leads to the practical realization but not as the beginning of the general project of the Description. It is to be anticipated before the same departure of the troops and it seems to us that it should be reasonably considered contemporary with the same resolution of the Directorate that decides the Campaign.

Jean-Antoine Chaptal's request for the formation of a Commission Spéciale is therefore not an independent idea but is part of a process that, in the light of history, transforms the prevailing sense of the Campagne d'Egypte from militaire to scientifique.

The procedure followed for the compilation of volumes also shows a priori planning. The research already published in the Courier, on the Decade and above all in the attached Mémoires on the Egypte had been addressed by Gaspard Monge, who interpreted his position as President of the Institut in a way that was anything but honorary and exercised full power of control, towards the production of homogeneous and interconnected material. Nonetheless, the process was onerous and gigantic and the final edition in the mammutfolio format of $1000 \times 801 \mathrm{~mm}$ (sometimes called éléphant) collects the representation in the form of a geometric and visual model of almost all the archaeological sites known at the time (figs. 9-I I) and of many of the significant architectural presences (fig. 12) and represents the real great undying success of the Campagne d'Egypte.

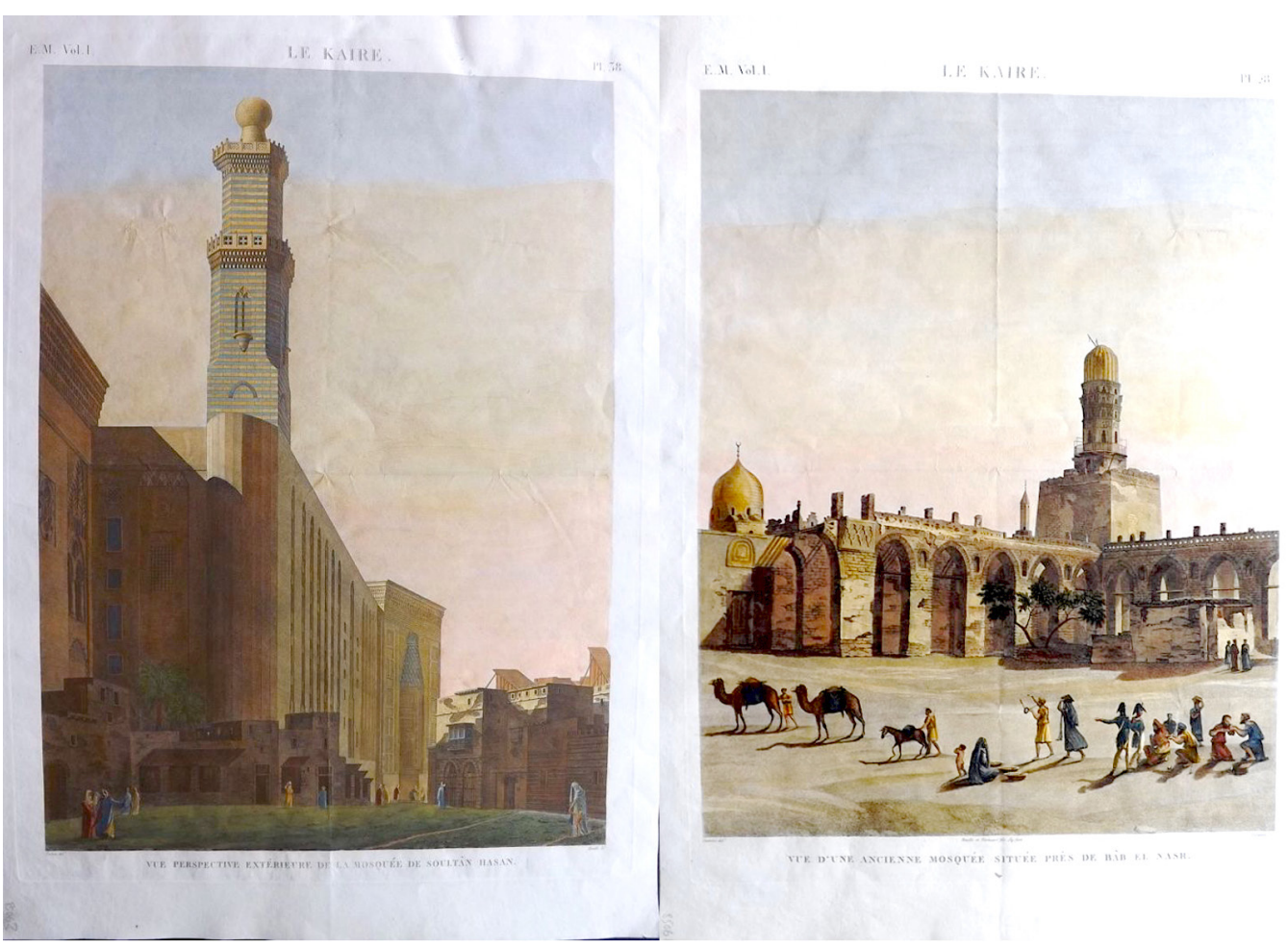

Notes

[I] Consider, by way of example, the volume Augusta Taurinorum of I 577 which traces the Piedmontese city itself to an unlikely Egyptian origin. A work that is anything but secondary, if we note as Emanuele Tesauro, a few decades later, writing the Historia della Augusta città di Torino, reaffirms and underlines the (imaginary) Egyptian roots of the House of Savoy.

[2] An example of the essentially exotic function of Egypt is given by Mozart's play The Magic Flute ( 179 |). The cult of Egyptian civilization was still a mass phenomenon. 


\section{References}

AA.W. (1809-1822). Description de l'Égypte ou recueil des observations et des recherches qui ont été faites en Égypte pendant l'expédition de l'armée française, publiée par les ordres de S.M. l'Empereur Napoléon. Paris: Imprimerie Impériale.

Aubry P.V. (1954). Monge, le savant ami de Napoléon: I 746- I 8 I 8. Paris: Gauthier-Villars. In De Launay, L. (ed.) (I933). Un grand français: Monge, fondateur de l'École Polytechnique. Paris: Roger.

Denon D.V. (1802). Voyage dans la Basse et la Haute Égypte pendant les campagnes du Général Bonaparte. Paris: Imprimerie de P. Didot.

Gillespie C. C. (1989). Aspects scientifiques de l'Expédition d'Égypte (|798-|80 I). In Laurens H. (ed.). L'expédition d'Égypte 1798-1801. Paris: Colin, pp. 37|-396.

Humbert J., Pantazzi M. M., Ziegler C. (1994). Egyptomania: L'Égypte dans l'art occidental: I 730- 1 930, Paris, Louvre, 20 jan- 8 avr. Catalogue. Paris: R. M. N

Laissus Y. (1960). Gaspard Monge et l'expédition en Égypte (1798-1799). In Revue de Synthèse, vol. XIX-XX, pp. $309-336$.

Laurens H. ( 1 988). Bonaparte, l'Orient et la Grande Nation. In Annales Historiques de la Révolution Française, n. 273, pp. 289-30 I.

Pepe L. (1996). Gaspard Monge in Italia: La formazione e i primi lavori dell'Istituto Nazionale della Repubblica Romana. In Bollettino di storia delle scienze matematiche, n. I6, pp. 45-100.

Taton R. (I95I). L'oeuvre scientifique de Gaspard Monge. Paris: P.U.F.

Vercoutter J. (1998). À la recherche de l'Égypte oubliée. Paris: Gallimard.

Wassef A.S. (1975). L'information et la presse officielle en Égypte jusqu'à la fin de l'occupation française. Le Caire: I.F.A.O.

\section{Author}

Daniele Giovanni Papi, Politecnico di Milano, daniele.papi@polimi.it

To cite this chapter. Papi Daniele Giovanni (2021). La campagna d'Egitto: il contributo essenziale di Bonaparte e Monge alla moderna egittologia/ The Egypt Campaign: the essential contribution of Bonaparte and Monge to modern egyptology. In Arena A., Arena M., Mediati D., Raffa P. (a cura di). Connettere. Un disegno per annodare e tessere. Linguaggi Distanze Tecnologie. Atti del $42^{\circ}$ Convegno Internazionale dei Docenti delle Discipline della Rappresentazione/Connecting. Drawing for weaving relationship. Languages Distances Technologies. Proceedings of the $42^{\text {th }}$ International Conference of Representation Disciplines Teachers. Milano: FrancoAngeli, pp. $1780-1795$. 